\title{
Proximate, vitamin and mineral assays of an underutilised indigenous vegetable in West Africa Salvia elegans Vahl (Lamiales: Lamiaceae) in enhancing diet diversification
}

\section{Oluwole Oladeji*, Tomilayo Amusan}

Department of Pure and Applied Chemistry. Ladoke Akintola University of Technology. P. M. B. 4000. Ogbomoso. Nigeria.*Email: oladejioluwole@gmail.com.

\begin{abstract}
The main objective of this research is to explore the proximate, minerals and vitamin assays of Salvia elegans Vahl (Lamiales: Lamiaceae) with the aim of promoting their consumption. Proximate analysis was carried out following the method described by the Association of Official Analytical Chemist (AOAC). Minerals was analysed by atomic absorption spectrophotometer and vitamins are analysed using high performance liquid chromatography. The proximate analysis moisture content of $(2.565 \pm 0.14)$, crude protein (24.24 \pm 0.13$)$, crude fibre (6.67 \pm 0.03$)$, ash (16.95 \pm 0.19$)$, CHO $(48.08 \pm 0.6$ cru g/100 gDM, calcium (265.25 mg/kg), iron (245.4 mg/g), sodium $(374.45 \pm 0.10 \mathrm{mg} / 100 \mathrm{~g})$, magnesium (76.53 mg/100 g), copper $(1.20 \mathrm{mg} / 100 \mathrm{~g})$, potassium (199.53 $\mathrm{mg} / 100 \mathrm{~g})$, Zn (102.90 mg/100 g), manganese (4.95 mg/100 g). Also contain $7.98 \mathrm{mg}$ of B1 (thiamine), $3.33 \mathrm{mg}$ of riboflavin, $48.93 \mathrm{mg}$ of niacin, ascorbic acid (252.02 mg/100 g), retinol (98.06 mg), cholecalciferol (8.64 mg) and tocopherols (10.97 mg). The consumption of $S$. elegans could complement other food sources in effecting positive impact of vitamins, fibres and minerals in supplementation on the growth of stunted children, building of bones, tissue formation and on the prevalence of disease such as typhoid, scurvy, and rickets. Therefore, the cultivation and consumption of the plant should be encouraged.
\end{abstract}

Keywords: Proximate analysis; Vitamins; Minerals; Human diet; Food security.

Resumo. Composição centesimal e análises vitamínicas e minerais de um vegetal nativo subutilizado na África Ocidental Salvia elegans Vahl (Lamiales: Lamiaceae) para a melhoria da diversificação da dieta. O objetivo principal desta pesquisa é analisar a composição centesimal e conteúdo de minerais e de vitaminas de Salvia elegans Vahl (Lamiales: Lamiaceae) com o intuito de promover seu consumo. A composição centesimal foi realizada seguindo o método descrito pela Associação de Químicos Analíticos Oficiais (AOAC). Os minerais foram analisados por espectrofotômetro de absorção atômica e as vitaminas foram analisadas por cromatografia líquida de alta eficiência. O teor de umidade $(2,565 \pm 0,14)$, proteína bruta $(24,24 \pm 0,13)$, fibra bruta $(6,67 \pm 0,03)$, cinzas $(16,95 \pm 0,19)$, carboidratos $(48,08 \pm 0,6$ cru g/100 gDM), cálcio $(265,25 \mathrm{mg} / \mathrm{kg})$, ferro $(245,4 \mathrm{mg} / \mathrm{g})$, sódio
Recebido:

25/10/2016

Aceito:

$19 / 12 / 2016$

Publicado:

$31 / 12 / 2016$

Acesso Aberto

Artigo completo

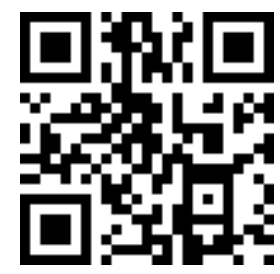

ORCID

(D) 0000-0003-3355-2488 Oluwole Oladeji

(1) 0000-0002-8973-3758

Tomilayo Amusan 
(374,45 \pm 0,10 mg/100 g), magnésio (76,53 mg/100 g), cobre $(1,20$ $\mathrm{mg} / 100 \mathrm{~g})$, Zn (102,90 mg/100 g), manganês (4,95 mg/100 g). Contém também 7,98 mg de B1 (tiamina), 3,33 mg de riboflavina, 48,93 mg de niacina, ácido ascórbico (252,02 mg/100 g), retinol (98,06 mg), colecalciferol (8,64 mg) e tocoferóis (10,97 mg). O consumo de $S$. elegans pode complementar outras fontes de alimento ao efetuar impacto positivo de vitaminas, fibras e minerais em suplementação ao crescimento de crianças atrofiadas, construção de ossos, formação de tecidos e na prevalência de doenças como febre tifoide, escorbuto e raquitismo. Portanto, o cultivo e o consumo dessa planta devem ser encorajados.

Palavras-chave: Composição centesimal; Vitaminas; Minerais; Dieta humana; Segurança alimentar.

\section{Introduction}

Salvia belongs to the Lamiaceae Family with a large genus containing about 500 species of sage plants throughout the world. Salvia elegans Vahl is commonly called pineapple sage or tangerine sage (Lara, 2006). It is a perennial shrub native to Mexico use in traditional medicine to alleviate central nervous system ailments (Aguilar et al., 1994). It is locally called Ewe-ribena (because of reddish-blood colour of the plant infusion).

Vegetables are an important component of the human diet, providing fibre, minerals, proteins and vitamins (Gupta et al., 2012) and are low in calories. They are also a very good source of antioxidants (Acikgoz, 2011). When the consumption of African leafy vegetables (ALVs) is increased, it will have a positive effect on nutrition, health and economic wellbeing of both rural and urban populations. Apart from promoting good health, it also helps to enhance crop diversity, alleviate poverty and promote food security. Green leafy vegetables are known to be low in calorie, contain low carbohydrate contents. These characteristics make them ideal for promoting and maintaining healthy body weight and coupled with the high fibre content, these vegetables particularly help with reducing type II diabetes.

This plant have been extensively studied for a variety of bioactive principles and screened for different pharmacological activities such as antidepressant and anxiolytic effects (Mora et al., 2006), activity on brain functioning, dietary, antibacterial (Selvakumar et al., 2012); anti histaminic (Maxia et al., 2010); anthelmintic (Zachariah et al., 2012) and anti-inflammatory (Maxia et al., 2010), medicinal and miscellaneous uses (Hanson, 2004). Research studies have revealed that wild or semi-wild plants are nutritionally important because of high vitamins, minerals, essential fatty acids and fibre contents. The plant is extensively used in Mexican traditional medicine, especially for the treatment of anxiety, and also for lowering of blood pressure.

Scientists suggested the need to consume high vegetable meals to prevent colon and stomach cancers. Others (Ball, 2006) reported on high vitamin, dietary fibre and mineral contents of vegetables and the role they play in maintaining alkalinity in the body. The high dietary fibre in green leafy vegetables helps regulate the digestive system aiding bowel health and for weight management. Several studies have shown that high folate intake from green leafy vegetables may lower the risk of colon polyps by 30 to 40 percent compared to low intake of this vitamin suggesting that diets low in folate may increase the risk of colon cancer (Panda, 2010). Low folate intake has also been associated with cancers of the breast, cervix and lung.

Despite the great value of these traditional leafy vegetables, not much research has been carried out on them 
especially in the area of nutritional and medicinal benefit of many indigenous green leafy vegetables which are under exploited or underutilized, this study is designed to analyse some of these vegetables which are regarded as weed by many in the Savannah Zone of Nigeria. The main objective of this research is to explore the proximate, minerals and vitamin assays of $S$. elegans with the aim of promoting their consumption and thus enhance diet diversification.

\section{Materials and methods}

\section{sample \\ Collection and identification of}

S. elegans was obtained from a farm located in Oshogbo, Osun State South-West geopolitical zone of Nigeria. The plant was identified and authenticated at the Forestry Research Institute of Nigeria (FRIN), Ibadan, with Voucher no FHI 11207 (S. elegans).

\section{Sample treatment and preparation}

The leaves were separated from the stalks, washed and air-dried for 25 days, pulverized into fine powder, sieved with a sieve of mesh size of $20 \mathrm{~mm}$ and stored in a clean, dry air-tight sampling bottle and kept at $4{ }^{\circ} \mathrm{C}$ until required for analysis. All reagents were of analytical grade and of sigma unless otherwise stated.

\section{Proximate analysis}

Proximate analysis was carried out following the method described by the Association of Analytical Chemists, (AOAC, 1990):

\section{Moisture content}

About $2.0 \mathrm{~g}$ of the sample was weighed $\left(\mathrm{W}_{1}\right)$ into pre-weighed crucible $\left(\mathrm{W}_{0}\right)$ and placed into a hot drying oven at $105^{\circ} \mathrm{C}$ for $24 \mathrm{~h}$. The crucible was removed, cooled in desiccator and weighed. The process of heating, cooling and weighing were repeated until a constant weight $\left(\mathrm{W}_{2}\right)$ was obtained.

\section{Ash content}

About $2.0 \mathrm{~g}$ of the sample was weighed $\left(\mathrm{W}_{1}\right)$ into pre-weighed empty crucibles $\left(\mathrm{W}_{0}\right)$ and placed into a Lenton furnace at $550{ }^{\circ} \mathrm{C}$ for $3 \mathrm{~h}$. The ash was cooled in desiccators and weighed $\left(\mathrm{W}_{2}\right)$. The weight of the ash was determined by the difference between the powdered leaf samples, pre-weighed crucible and the ash in the crucible.

\section{Crude lipids}

About 2.0 g was accurately weighed $\left(\mathrm{W}_{0}\right)$ into a porous thimble and covered with a clean white cotton wool. Petroleum ether $(200 \mathrm{~mL})$ was poured into a $250 \mathrm{~mL}$ extraction flask, which was previously dried in the oven at $105^{\circ} \mathrm{C}$ and weighed $\left(\mathrm{W}_{2}\right)$. The porous thimble was placed into the Soxhlet and the rest of the apparatus was assembled. Extraction was done for $5 \mathrm{~h}$. The thimble was removed carefully and the extraction flask placed in a water bath so as to evaporate the petroleum ether and then dried in the oven at a temperature of $105{ }^{\circ} \mathrm{C}$ to completely free the solvent and moisture. It was then cooled in desiccators and reweighed $\left(\mathrm{W}_{1}\right)$. The percentage crude lipid was calculated using the equation below:

$$
\text { \%Crude Lipid }=\frac{W_{1}-W_{2}}{W_{0}} \times 100
$$

Where: $\mathrm{W}_{0}=$ Weight of sample (g); $\mathrm{W}_{1}=$ Weight of Flask + oil (g); $\mathrm{W}_{2}=$ Weight of flask (g).

\section{Crude fibre content}

About $2.0 \mathrm{~g}$ of the sample was accurately weighed $\left(\mathrm{W}_{\theta}\right)$ into a $1 \mathrm{dm}^{3}$ conical flask. About $100 \mathrm{~mL}$ of distilled water and $20 \mathrm{~mL}$ of $20 \%$ sulphuric acid were added and boiled gently for $30 \mathrm{~min}$. The content was filtered through Whatman No. 1 filter paper. The residue was scrapped back into the flask with a spatula. Water $(100 \mathrm{~mL})$ and $20 \mathrm{~mL}$ of $10 \%$ sodium hydroxide were added and allowed to boil gently for $30 \mathrm{~min}$. The content was filtered and the residue was washed thoroughly with hot distilled water, it was then rinsed 
once with $10 \%$ hydrochloric acid and twice with ethanol and finally three times with petroleum ether. It was allowed to dry and scrapped into the crucible and dried overnight at $105{ }^{\circ} \mathrm{C}$ in an air oven. It was then removed and cooled in the desiccators. The sample was weighed $\left(\mathrm{W}_{1}\right)$ and ashed at $600{ }^{\circ} \mathrm{C}$ for $90 \mathrm{~min}$ in a Lenton muffle furnace. It was finally cooled in desiccators and weighed again $\left(\mathrm{W}_{2}\right)$. The percentage crude fibre was calculated using equation:

$$
\% \text { Crude fibre }=\frac{W_{1}-W_{2}}{W_{0}} \times 100
$$

Where: $\mathrm{W}_{0}=$ weight of sample (g); $\mathrm{W}_{1}=$ weight of dried sample (g); $\mathrm{W}_{2}=$ weight of ash sample (g).

\section{Crude protein}

About $2.0 \mathrm{~g}$ was accurately weighed along with $20 \mathrm{~mL}$ of distilled water into a micro-Kjeldahl's digestion flask. It was shaken and allowed to stand for sometimes. One tablet of selenium catalyst was added followed by the addition of $20 \mathrm{~mL}$ concentrated sulphuric acids. The flask was heated on the digestion block at $100{ }^{\circ} \mathrm{C}$ for $4 \mathrm{~h}$ until the digest became clear. The flask was removed from the block and allowed to cool. The content was transferred into $50 \mathrm{~mL}$ volumetric flask and an aliquot of the digest $(10 \mathrm{~mL})$ was transferred into another micro-Kjeldahl's flask along with $20 \mathrm{~mL}$ of distilled water, and placed in the distilling outlet of the micro-Kjeldahl's distillation unit. A conical flask containing $20 \mathrm{~cm}^{3}$ of boric acid indicator was placed under the condenser outlet. Sodium hydroxide solution $(20 \mathrm{~mL}$, $40 \%$ ) was added to the content in the Kjeldahl's flask by opening the funnel stopcock. The distillation was started and the heat supplied was regulated to avoid sucking back. When all the available distillate was collected in $20 \mathrm{~mL}$ of boric acid, the distillation was stopped. The nitrogen in the distillate was determined by titrating with $0.01 \mathrm{M}$ of $\mathrm{H}_{2} \mathrm{SO}_{4}$; the end point was obtained when the colour of the distillate changed from green to pink. The crude protein was calculated using equation below:

$\%$ Crude protein $=\% \mathrm{~N}$ x 6.60

The nitrogen content of the sample is given by the formula below:

$$
\% N=\frac{T_{V} N a \times 0.014 \times V_{1} \times 100}{G \times V_{2}}
$$

Where: $\mathrm{T}_{\mathrm{v}}=$ Titre value of acid $\left(\mathrm{cm}^{3}\right) ; \mathrm{Na}=$ Concentration or normality of acid $\left(\mathrm{mol} / \mathrm{dm}^{3}\right) ; \mathrm{V}_{1}=$ Volume of distilled water used for distilling the digest $\left(50 \mathrm{~cm}^{3}\right)$; $\mathrm{V}_{2}=$ Volume of aliquot used for distillation $\left(10 \mathrm{~cm}^{3}\right) ; \mathrm{G}=$ Original weight of sample used (g).

\section{Carbohydrates}

The method of James (1995) was adopted where the total proportion of carbohydrate in the leaves sample was estimated by difference. That is by subtracting the \% sum of food nutrients: \% protein, \% crude lipids, \% crude fibre and $\%$ ash from $100 \%$. This is done by using the equation below:

$$
\% \mathrm{CHO}=100 \% \text { - (\% Crude protein }+
$$

$\%$ Crude lipid $+\%$ Crude fibre $+\%$ ash)

\section{Mineral analysis}

The mineral elements comprising sodium, calcium, potassium, magnesium, iron, zinc, copper, manganese, nickel and lead were identified. Atomic absorption spectrophotometer was used to analyze the minerals separately after acid digestion of the sample, as described in the official method of the Association of Official Analytical Chemists.

About $2.0 \mathrm{~g}$ was accurately weighed and subjected to dry ashing in a well-cleaned porcelain crucible at $550^{\circ} \mathrm{C}$ in a muffle furnace. The resultant ash was dissolved in $5.0 \mathrm{~mL}$ of $\mathrm{HNO}_{3} / \mathrm{HCl} / \mathrm{H}_{2} \mathrm{O}$ $(1: 2: 3)$ and heated gently on a hot plate until brown fumes disappeared. To the remaining material in each crucible, $5.0 \mathrm{~mL}$ of de-ionized water was added and heated until a colourless solution was obtained. 
The mineral solution in each crucible was transferred into a $100.0 \mathrm{~mL}$ volumetric flask by filtration through Whatman No.42 filter paper and the volume was made to the mark with de-ionized water. This solution was used for elemental analysis by atomic absorption spectrophotometer. A $10 \mathrm{~cm}$ long cell was used and concentration of each element in the sample was calculated on percentage (\%) of dry matter i.e. mg $/ 100$ g sample.

\section{Vitamin assays}

For buffer preparation, $1.08 \mathrm{~g}$ of hexane sulphonic acid sodium salt and $1.36 \mathrm{~g}$ of potassium dihydrogen phosphate were dissolved in $940 \mathrm{~mL}$ of HPLC water and $5 \mathrm{~mL}$ of triethylamine was added to it and the $\mathrm{pH}$ was adjusted to 3.0 with orthophosphoric acid. To prepare the mobile phase, buffer and methanol were mixed with a ratio of 96:4 and filtered through $0.45 \mu$ membrane filter and degassed by using helium gas. Calibration curve was made by using mix standards in mobile phase with five point calibrations, analyzed independently by HPLC and a standard curve was plotted between concentration and peak area. The data of peak areas and the used standard vitamin concentration were treated by linear leastsquare regression and the regression equation thus obtained from standard curve, was used to estimate water-soluble and fat soluble vitamins in different samples.

\section{Statistical analyses}

The data obtained from the analysed samples was summarized into mean and standard deviation using ANOVA for comparison with the aid of Turkey HSD test at $<0.05$ significant level.

\section{Results and discussion}

\section{Proximate composition}

The proximate analysis (Table 1 ) of moisture content of (2.565 \pm 0.14$)$, crude protein (24.24 \pm 0.13$)$, crude fibre (6.67 \pm 0.03$)$, ash (16.95 \pm 0.19$)$, $\mathrm{CHO}$ $(48.08 \pm 0.6)]$ cru $\mathrm{g} / 100 \mathrm{~g} \quad \mathrm{DM}$ was obtained from the proximate composition of S. elegans sample. S. elegans contain high amount of carbohydrate with the least found in crude fibre. When compared to the reference standard (Amarathus Hybridus), they have less composition except in carbohydrate where $S$. elegans contains higher amount of $\mathrm{CHO}(48.08 \pm 0.6)$ to reference of $(15.40 \pm 0.02)$. The low moisture content of these leafy vegetables will help to prolong their shelf life.

Table 1. Proximate composition of Salvia elegans (g/100g) dry weight and some common vegetables.

\begin{tabular}{lcccccc}
\hline Plant samples & Moisture & $\begin{array}{c}\text { Crude } \\
\text { protein \% }\end{array}$ & $\begin{array}{c}\text { Crude } \\
\text { fibre\% }\end{array}$ & Ash\% & CHO \% & $\begin{array}{c}\text { Crude } \\
\text { fat \% }\end{array}$ \\
\hline Salvia elegans & $2.565 \pm 0.14$ & $24.24 \pm 0.13^{\mathrm{a}}$ & $6.67 \pm 0.03^{\mathrm{a}}$ & $16.95 \pm 0.1^{\mathrm{a}}$ & $48.08 \pm 0.6^{\mathrm{a}}$ & $1.48 \pm 0.04^{\mathrm{a}}$ \\
Amarathus hybridus* & $8.35 \pm 0.0$ & $32.95 \pm 0.01$ & $19.60 \pm 0.01$ & $17.70 \pm 0.1$ & $15.40 \pm 0.02$ & $1.61 \pm 0.02$ \\
Vernonia amygdalina & 21.9 & 14.9 & 1.0 & - & 48.2 & - \\
Senecio biafrae & 28.0 & 12.3 & 11.80 & - & 30.0 & - \\
\hline
\end{tabular}

Mean \pm standard deviation of triplicate determinations

Mean with the same superscript in the same column are not significantly different at 5\% probability level. Amarathus hybridus*(used as standard being a conventional vegetable; Values from (Akubugwo 2007).

The crude protein content on dry weight basis of $S$. elegans ranges between $24.2 \pm 0.13 \mathrm{~g} / 100 \mathrm{~g}$, which is considerably higher when compared to conventional vegetables such as Vernonia amygdalina and Senecio biafrae of 21.9 and $28.0 \mathrm{~g} / 100 \mathrm{~g}$, respectively (Akubugwo, 2007), leisanthera african having 13.1-14.9 g/100 g (Isong et al., 1999) and lower than Piper guinese with 
$29.78 \mathrm{~g} / 100 \mathrm{~g}$ (Akindahunsi et al., 2005). These samples can complement other dietary source of protein for the alleviation of protein malnutrition. The high crude protein composition of $S$. elegans indicated that it contains high calorific protein value and this is considered good source of protein.

The crude fat content of $1.5 \pm 0.04 \mathrm{~g} / 100 \mathrm{~g}$ DW for $S$. elegans is low compared to reported values (8.3-2.7 g/100 g DW) in some vegetables consumed in West Africa (Ifon and Basir, 1980). Vegetables such as (S. elegans) are poor sources of fat and this is of great benefit for people that requires less fat in their diet because high amount of fat have implication on health related disease and cardiovascular disorder (Anita et al., 2006).

The carbohydrate content of $48.08 \pm 0.6 \mathrm{~g} / 100 \mathrm{~g}$ DW for $S$. elegans was found to be higher when compared to Amarathus incurvatus (20\% DW), M. balsamina leaf $23.7 \%$ (Faruq et al., 2002, Hassan, 2006); lower when compared to Tribulus terrestris $55.56 \%$, water spinach leaves 54.20\%, (Asibey et al., 1999). The high amount of carbohydrate in $S$. elegans indicates it can serve as a source of energy.

The crude ash content of $16.97 \pm 0.1$ was obtained for $S$. elegans; this indicates that the plants are rich in mineral elements. The values obtained was higher compared to $1.8 \%$ reported in sweet potatoes leaves (Asibey-Berko et al., 1999) thus this indicate that these vegetables are good sources of minerals, but lower when compared to $19.61 \%$ in Amaranthus hydridus leaves (Nwaogu et al., 2000) and $18.00 \%$ balsam apple leaves (Hassan and Umar, 2006).

The crude fibre content of $6.67 \pm 0.03 \mathrm{~g} / 100 \mathrm{~g}$ in S.elegans; this was high compared to reported values of T. triangulare 6.20\% (Anita et al., 2006) and low when compared to $29.00 \%$ balsam apples leaves (Hassan and Umar, 2006), I. batatas $7.20 \%$ (Akindahunsi et al., 2005). The high amount of dietary fibre in S. elegans helps to lower serum, cholesterol level, risk of coronary heart disease, hypertension, constipation, diabetics, colon and breast cancer (Ishida et al., 2000). The RDA of dietary fibre for children for adults, pregnant and lactating mothers are 19-25, 21-38, 28 and $29 \mathrm{~g}$, respectively, thus S. elegans can be a good source of dietary fibre because it has a high fibre content. The estimated calorific value of $243.18 \mathrm{kcal}$ was obtained in $S$. elegans. Thus, the calorific value agrees with the general observation that vegetables with high calorific value have low energy values due to their low fat content (Sobowale et al., 2011).

\section{Concentration of mineral elements by AAS}

The concentration of different mineral elements in three vegetables samples were determined using Atomic absorption spectrophotometric technique (AAS) were reported in Table 2. Food minerals are important in our diets, they serve as cofactors for many physiological and metabolic function; they are of interest due to their pro- oxidant activities and health benefit (Alpha et al., 1996).

Calcium is a major factor for sustaining strong bone, and plays an important role in muscle contraction and relaxation, blood clothing, synaptic transmission and absorption of vitamin $\mathrm{B}_{12}$ (Mensah, 2008). S. elegans contains calcium of $265.25 \mathrm{mg} / \mathrm{kg}$ was found to be high when compared to $17.95 \mathrm{mg} / 100 \mathrm{~g}$ in Cassia siemea leaves and $44.15 \mathrm{mg} / 100 \mathrm{~g}$ in Amaranthus hydridus (Akubugwo et al., 2007) but lower when compared to $941 \mathrm{mg} / 100 \mathrm{~g}$ in Mormordica balsamma (Hassan and Umar, 2006).

Iron is an essential trace element in food and vegetables. They help in haemoglobin formation and in the oxidation of carbohydrates, protein and fat in the body (Adeyeye et al., 1999). S. elegans has iron content of $245.4 \mathrm{mg} / \mathrm{g}$ and was found to be higher compared to $13.58 \mathrm{mg} / 100 \mathrm{~g}$ of Amaranthus hydridus (Akubugwo, 2007), $16.0 \mathrm{mg} / 100 \mathrm{~g}$ of Ipomea batatas (Anita et al., 2000). 
Table 2. Level of some mineral nutrients in the leaves of S. elegans and some common vegetables.

\begin{tabular}{lcccc}
\hline $\begin{array}{l}\text { Mineral } \\
\text { elements }\end{array}$ & $\begin{array}{c}\text { S. elegans } \\
(\mathbf{m g} / \mathbf{1 0 0 g})\end{array}$ & $\begin{array}{c}\text { V. amygdalina } \\
\left.(\mathbf{g} / \mathbf{1 0 0} \mathbf{g ~ D M}) \mathbf{( *}^{*}\right)\end{array}$ & $\begin{array}{c}\text { A. hybrids } \\
\left.(\mathbf{g} / \mathbf{1 0 0} \mathbf{g ~ D M}) \mathbf{( *}^{*}\right)\end{array}$ & $\begin{array}{c}\text { \%RDA(Male } \\
\text { adults) }\end{array}$ \\
\hline $\mathbf{N a}$ & $374.45 \pm 0.10$ & 0.04 & 6.85 & $1.5 \mathrm{~g} / \mathrm{day}$ \\
$\mathbf{K}$ & $199.03 \pm 0.50$ & 3.76 & 4.83 & $8 \mathrm{mg} / \mathrm{day}$ \\
$\mathbf{Z n}$ & $102.7 \pm 0.52^{\mathrm{a}}$ & - & - & $1300 \mu \mathrm{\mu g} / \mathrm{day}$ \\
$\mathbf{C a}$ & $265.38 \pm 0.04^{\mathrm{a}}$ & 2.26 & 2.06 & $4.5 \mathrm{~g} / \mathrm{day}$ \\
$\mathbf{M g}$ & $76.78 \pm 0.20$ & 0.46 & 2.54 & $11 \mathrm{mg} / \mathrm{day}$ \\
$\mathbf{F e}$ & $245.6 \pm 0.04$ & 0.03 & 0.13 & $420 \mathrm{mg} / \mathrm{day}$ \\
$\mathbf{M n}$ & $4.97 \pm 0.070^{\mathrm{a}}$ & - & - & $2.3 \mathrm{mg} / \mathrm{day}$ \\
$\mathbf{C u}$ & $1.24 \pm 0.25^{\mathrm{a}}$ & - & - & $900 \mu \mathrm{dg} / \mathrm{day}$ \\
$\mathbf{P b}$ & $\mathrm{ND}$ & - & - & - \\
$\mathbf{N i}$ & $\mathrm{ND}$ & - & - & - \\
\hline
\end{tabular}

Reference vegetable source (*): Ajiboye et al. (2014).

ND: Not detected, RDA: Recommended daily allowance; source of values (Food and Nutrition Board, 2011).

Mean \pm standard deviation of triplicate determinations.

Mean on the same rows are compared using different alphabet superscript, i.e.mean values have the same alphabet are not significantly different at 5\% probability level.

Sodium is regarded as the principal cation in intracellular fluids. They helps regulates plasma volume and acid-base balance, involved in maintenance of osmotic pressure of the body fluids and involved in $\mathrm{Na}^{+} / \mathrm{K}^{+}$-ATPase, maintenance of membrane potentials transmission of nerve impulses and adsorptive processes of monosaccharide, amino acid, pyrimidine and bile. The level of sodium was to be $374.45 \pm 0.10 \mathrm{mg} / 100 \mathrm{~g}$ was found high compared to $45 \pm 0.15 \mathrm{mg} / 100 \mathrm{~g}$ of Senna obtusfolia.

The magnesium content of $76.53 \mathrm{mg} / 100 \mathrm{~g}$ was obtained for $S$.elegans was high compared to $23.18 \mathrm{mg} / 100 \mathrm{~g}$ of Amaranthus hydridus (Nwaogu et al., 2006). The RDA value for magnesium for adults male is $350 \mathrm{mg}$ as stated by NRC, (1989); S. elegans vegetables contribute $21.86 \%$ to the Recommended Daily Allowance.

Copper is a constituent of enzymes like cytochrome oxidase, catalase peroxidase, ascorbic acid oxidase and plays an important role in iron absorption (Chandra et al., 2003). The copper content of $1.20 \mathrm{mg} / 100 \mathrm{~g}$ was obtained in S. elegans and was found higher compared to $0.90 \mathrm{mg}$ $/ 100 \mathrm{~g}$ in Cassia siemea leaves and lower to
$1.28 \mathrm{mg} / 100 \mathrm{~g}$ in $T$. terrestris leaves. The RDA values for copper are 1.5-3 mg for male adults. $S$. elegans have value in between the RDA value for copper, thus implies that the vegetable is a good source of copper.

Potassium plays an important role in controlling skeletal muscles and normal functioning of body tissues and bones formation (Mensah et al., 2008). Potassium content of $S$. elegans was found to be $199.53 \mathrm{mg} / 100 \mathrm{~g}$ and was high when compared to $54.20 \mathrm{mg} / 100 \mathrm{~g}$ of Amaranthus viridis (Akubugwo et al., 2007) and lower when compared to 220.00 mg/100 g in Cassia siemea leaves.

Zinc is a co-factor and constitute of many enzymes dehydrogenase, glutamic dehydrogenase amongst others. They assisted enzymes in macronutrient metabolism and cell replications (Arinola et al., 2008). It is also needed for tissues repairs such as $\mathrm{Zn}$ is an integral constituent of insulin. The $\mathrm{Zn}$ content of S. elegans was found to be $102.90 \mathrm{mg} / 100 \mathrm{~g}$ was found to be higher when compared to $6.85 \mathrm{mg} / 100 \mathrm{~g}$ in Cassia siemea.

Manganese is another microelement essential for human nutrition. S. elegans has manganese level of 4.95 
$\mathrm{mg} / 100 \mathrm{~g}$ and this falls within the range $0.98-38.0 \mathrm{mg} / 100 \mathrm{~g}$ of some locally green leafy vegetables (Hassan and Umar, 2006). The RDA value for Manganese is 2-5 $\mathrm{mg} / 100 \mathrm{~g}$ for male adults. Because of this, $S$. elegans can be a good source of manganese.

From the result, it can be infer that the consumption of $S$. elegans could complement other food sources in effecting positive impact of $\mathrm{Zn}, \mathrm{Mg}, \mathrm{Fe}, \mathrm{Na}, \mathrm{Cu}, \mathrm{Ca}$, $\mathrm{K}$ and $\mathrm{Mn}$ in supplementation on the growth of stunted children, building of bones and muscles, tissue formation, antigens, antibodies and on the prevalence of selected childhood disease such as diarrhoea, typhoid, scurvy, rickets (Hassan et al., 2009).

\section{Vitamins composition}

Vitamins are one of the major constituents of food including fruits and vegetables. They can be defined as organic compounds occurring in natural foods especially in vegetables either as such or as utilizable "precursors". They serve many purposes; these include maintenance of skin, mucus, membranes, bones, teeth and hair, vision and reproduction, help body to absorb calcium and phosphorus which are essential for bone development and

maintenance (Rumeza et al., 2006). They are known to assist in blood clotting, normal functioning of nervous system and endocrine glands).

Vitamin $\mathrm{B}_{1}, \mathrm{~B}_{2}, \mathrm{~B}_{3}$ (Thiamine, Riboflavin and Niacin) respectively are members of Vitamin B Complex. From Table 3, S. elegans contains $7.98 \mathrm{mg}$ of B1 (Thiamine), $3.33 \mathrm{mg}$ of Riboflavin and $48.93 \mathrm{mg}$ of Niacin. From the results, Niacin was found to have the highest content and this could be responsible for the use of the leaf to act as co-enzymes in various oxidative reactions. They contains riboflavin which could help to release energy from foods, promotes good vision and healthy skin. It also helps to convert the amino acids tryptophan into Niacin (Bellows and Moore, 2012). Thiamine is necessary for the normal metabolism of carbohydrate; its deficiency causes anorexia, fatigue, constipation and retarded growth (Rumeza et al., 2006). Deficiency of riboflavin in human produces lesion in the corner of mouth, inflammation of tongue (glossitis) and lesion on the lips and around the eyes and nose (Khalil, 2004).

Table 3. Some vitamin composition of Salvia elegans (mg/100g) and some common vegetables.

\begin{tabular}{lccccc}
\hline Vitamins & S. elegans & $\begin{array}{c}\text { Moringa } \\
\text { oleifera (*) }\end{array}$ & $\begin{array}{c}\text { Solanum } \\
\text { aethiopicum (*) }\end{array}$ & $\begin{array}{c}\text { Solanum } \\
\text { macrocarpon (*) }\end{array}$ & $\begin{array}{c}\text { \%RDA (male } \\
\text { adult) }\end{array}$ \\
\hline A (Retinol) & 340.50 & 108.48 & 94.66 & 92.45 & $700 \mu \mathrm{dg} / \mathrm{day}$ \\
B1 (Thiamine) & 7.98 & - & - & - & $1.1 \mathrm{mg} / \mathrm{day}$ \\
B2 (Riboflavin) & 3.33 & - & - & - & $1.1 \mathrm{mg} / \mathrm{day}$ \\
B3 (Niacin) & 48.93 & - & - & - & $12 \mathrm{mg} / \mathrm{day}$ \\
C (Ascorbic Acid) & 517.05 & 0.56 & 1.21 & 1.62 & $75 \mathrm{mg} / \mathrm{day}$ \\
D (Cholecalciferol) & 33.88 & - & - & - & $10 \mu \mathrm{g} / \mathrm{day}$ \\
E (Tocopherols) & 13.23 & 4.95 & 7.34 & 4.97 & $12 \mu \mathrm{g} / \mathrm{day}$ \\
\hline
\end{tabular}

RDA: Recommended daily allowance; Source of values: Food and Nutrition Board (2011).

Reference Vegetable Source (*): Achikanu et al. (2013).

Vitamin $\mathrm{C}$ also known as ascorbic acid is a water soluble vitamin required in high amount by the body for normal growth, development and functioning of the body system. They help prevent scurvy disease and also aids in the formation of folic acid derivatives which are essential for DNA synthesis (Chatterjee and Shinde, 1998). From table 3, S. elegans had the highest amount of $252.02 \mathrm{mg} / 100 \mathrm{~g}$ compared to $0.56 \mathrm{~g} / 100 \mathrm{~g}$ of Moringa oleifera. These results suggest that this 
vegetable is a good source of vitamin C when compared to the daily recommended intake of ascorbic acid which is $40 \mathrm{mg}$ as reported by Chinma and Igyor (2007).

Fat soluble vitamins determined were A, D and E. Vitamin A (Retinol) was found to be $98.06 \mathrm{mg}$ in Salvia elegans. they have high retinol percentage when compare to that of Moringa oleifera (108.48 mg), Solanum aethiopicum (94.66 mg) and Solanum macrocarpon (92.45 mg). Salvia elegans plays an important role in vision, bone growth, reproduction and immunity (Livestrong.com, 2014). Vitamin D (Cholecalciferol) was found to be $8.64 \mathrm{mg}$ in Salvia elegans. Vitamin D in Salvia elegans could be responsible for enhancing intestinal absorption of calcium, iron, magnesium, phosphate and zinc (Wolf, 2004). Vitamin E was found to be $10.97 \mathrm{mg}$ in Salvia elegans which is significantly higher when compare to Moringa oleifera (4.95 mg), Solanum aethiopicum (7.34 mg) and Solanum macrocarpon (4.97 mg). Tocopherols acts as an anti-oxidant, enzymatic activity regulator, neurological function and also protect lipids and prevent oxidation of polyunsaturated fatty acids (Whitney, 2011).

\section{Conclusion}

An increased consumption of $S$. elegans can have a positive effect on nutrition, health and economic wellbeing of both rural and urban populations. The presence of important compounds such as vitamins, minerals such as iron, calcium amongst others shows that the plant is important and could serve as supplementary in case of situation where there is no other means. Therefore, the plant cannot be only regarded as weeds, but as vegetable; they could help in health management and especially lowering risk of chronic human ailments such as cancer, cardiovascular diseases and other age related disorderliness, improve growth and development of the body including bones and skeleton.

\section{Acknowledgements}

The authors appreciate the efforts of Professor M.O. Bello of the Department of Pure and Applied Chemistry, Lautech, Ogbomoso, Nigeria for her contributions during the course of the study.

\section{Conflict of interest statement}

Authors declare that they have no conflict of interests.

\section{References}

Adeyeye, E. I.; Otokiti, M. K. Proximate composition and some nutritionally valuable minerals of two varieties of Capsicum annum (Bell and Cherry peppers). Discovery and Innovation, v. 11, p. 75-81, 1999.

Aguilar, A.; Camacho, J. R.; Chino, S.; Vazquez, P.; López, P. Herbario Medicinal del Instituto Mexicano del Seguro Social. Journal of Ethnobotanical, Mexico, v. 9, p. 107, 1994.

Akindahunsi, A. A.; Salawu, S. O. Photochemical screening and nutrient-antinutrient composition of selected tropical green vegetables. African Journal of Biotechnology, v. 4, p. 497-501, 2005.

Akubugwo, I. E.; Obasi, N. A.; Chinyere, G. C.; Ugbogu, A. E. Nutritional and chemical value of Amaranthus hybridus L. leaves from Afikpo. Nigeria African Journal of Biotechnology, v. 6, no. 24, p. 2833-2839, 2007.

Alpha, E.; Bala M.; Ackurt, F.; Yilmaz, T. Nutritional composition of hazenuts and its effects on glucose and lipid metabolism. Acta Horticulturae, v. 445, p. 305-310, 1996. http://dx.doi.org/10.17660/ActaHortic.1997.445.41

Antia, B. S.; Akpan, E. J.; Okon, P. A.; Umoren, I. U. Nutritive and anti-nutritive evaluation of sweet potatoes (Ipomoea batatas) leaves. Pakistan Journal of Nutrition, v. 5, no. 2, p. 166-168, 2006.

AOAC - Association of Official Analytical Chemists. Official methods of analysis. 15. ed. Washington, D. C., Association of Official Analytical Chemists, 1990.

Asibey-Berko, E.; Tayie, F. A. Poximate analysis of some underutilized Ghanaian vegetables. Ghana Journal of Science, v. 39, p. 91-92, 1999. 
Bellows, L. R.; Moore, R. Water soluble vitamins: B-Complex and vitamin C. Food and Nutrition Series, Health, Colorado State University Extension, Fact Sheet no. 9.312, 2012. Available from: $<$ http://extension.colostate.edu/docs/pubs/foodn ut/09312.pdf>. Accessed on: Sept. 22, 2016.

Chadha, M. L. AVRDC's experiences within marketing of indigenous vegetables: a case study on commercialization of African Eggplant. Arusha, Tanzani: AVRDC Regional Center for Africa Duluti, 2003.

Chatterjea, M. N.; Shinde, R. Textbook of Medical Biochemistry. 3. ed. New Delhi: Jaypee Brothers Medical Publishers, 1998.

Chinma, C. E.; Igyor, M. A. Micronutrients and anti-nutritional contents of selected tropical vegetables grown in Southeast Nigeria. Nigeria Food Journal, v. 25, no. 1, p. 111-116, 2007.

Gupta, S.; Lakshmi, A. J.; Majunath, M. N.; Prakash, J. Analysis of nutrient and antinutrient content of underutilized green leafy vegetables. LWT - Food Science. Technology, v. 38, p. 339-345, 2005.

Hassan, L. G.; Umar, K. J. Nutritional value of Balsam Apple (Momordica balsamina L.) leaves. Pakistan Journal of Nutrition, v. 5, no. 6, p. 522-529, 2006.

Ishida, H.; Suzuno, H.; Sugiyama, N.; Innami S.; Todokoro, T.; Maekawa, A. Nutritional evaluation of chemical component of leaves, stalks and stems of sweet potatos (Ipomoea batatas ). Journal of Food Chemistry, v. 68, p. 359-367, 2000.

Isong, E. U.; Adewusi, S. A. R.; Nkanga E. U.; Umoh, E. E.; Offiong, E. E. Nutritional and phytogeriatological studies of three variation of Gnetum africanum ("afang”). Journal of Food Chemistry, v. 64, p. 489-493, 1999.

Khali, I. A.; Saleemulla, A. Chemistry One. Bio-Analytical Chemistry. Pakistan: T. S. Printers, 2004.

Lara, C. Temporal dynamics of flower use by hummingbirds in a highland temperate forest in Mexico. Ecoscience, v. 13, no. 1, p. 23-29, $2006 . \quad$ http://dx.doi.org/10.2980/11956860(2006)13[23:TDOFUB]2.0.CO;2

Lintas, C. Nutritional aspects of fruits and vegetables consumption. Journal of Nutrition, v. 19, p. 79-87, 1992.
Maxia, A.; Sanna, C.; Salve, B.; Kasture, A.; Kasture, S. Inhibition of histamine mediated responses by Mirabilis jalapa: confirming traditional claims made about antiallergic and antiasthmatic activity. National Journal of Produce, v. 24, no. 18, p. 1681-1687, 2010.

Mensah, J. K.; Okoli, R. I.; Ohaju-Obodo, J. O.; Eifediyi K. Phytochemical, nutritional and medical properties of some leafy vegetables consumed by Edo People of Nigeria. African Journal of Biotechnology, v. 7, no. 14, p. 2304-2309, 2008.

Mora, S.; Diaz-Veliz, G.; Lungenstrass, H.; Garcia-Gonzalez, M.; Coto-Morales, T.; Poletti, C.; Lima, T. C.; Herrera-Ruiz, M.; Tortoriello, J. The hydroalcoholic extract of Salvia elegans induces anxiolytic- and antidepressant-like effects in rats. Journal of Ethnopharmacology, v. 97, p. 191-197, 2005.

Panda, P. Effects of green leafy vegetables and fruits on health. Journal of the Science of Food and Agriculture, v. 7, no. 4, p. 145-151, 2010.

Rumeza, H.; Zafar I.; Mudassar, I.; Shaheena, H.; Masooma, R. Use of vegetables as nutritional food: role in human health. Journal of Agricultural and Biological Science, v. 1, no. 1, p. 40-46, 2006.

Sobowale, S. S.; Olatidoye, O. P.; Olorode, O. O.; Akinlotan, J. V. Nutritional potentials and chemical value of some tropical leafy vegetables consumed in South West Nigeria J. Sci. Multidisciplinary Res., v. 3, p. 55-65, 2011.

Turan, M.; Kordis, S.; Zeyin, H.; Dursan, A.; Sezen, Y. Macro and micro minerals content of some wild edible leaves consumed in eastern Anatolia. Tailors and Francis Journal, v. 8, p. 129-130, 2003.

Wolf, G. The discovery of vitamin D: the contribution of Adolf Windaus. Journal of Nutrition, v. 134, no. 6, p. 1299-1302, 2011. Available from: <http://jn.nutrition.org/content/ 134/6/1299.full.pdf+html>. Accessed on: Sept. 22, 2016.

License information: This is an open-access article distributed under the terms of the Creative Commons Attribution License, which permits unrestricted use, distribution, and reproduction in any medium, provided the original work is properly cited. 